\title{
Micromechanical Coupled Study of Crack Growth Initiation Criterion in Pressure Vessel Steel
}

\author{
M. Rakin, ${ }^{a}$ A. Sedmak, ${ }^{b}$ Z. Cvijovic, ${ }^{a}$ M. Zrilic, ${ }^{a}$ and S. Sedmak ${ }^{a}$ \\ a Belgrade University, Faculty of Technology and Metallurgy, Belgrade, Serbia and \\ Montenegro \\ b Belgrade University, Faculty of Mechanical Engineering, Belgrade, Serbia and \\ Montenegro
}

УДК 539.4

\section{Комплексное микромеханическое исследование на основе критерия инициации трещины при вязко разрушении корпусных сталей}

\author{
М. Ракин ${ }^{a}$, А. Седмак \\ ${ }^{a}$ Белградский университет, факультет технологии и металлургии, Белград, Сербия и \\ Черногория \\ ${ }^{\text {б } Б е л г р а д с к и и ̆ ~ у н и в е р с и т е т, ~ ф а к у л ь т е т ~ м а ш и н о с т р о е н и я, ~ Б е л г р а д, ~ С е р б и я ~ и ~ Ч е р н о г о р и я ~}$ \\ Представлень результатьл комплексного расчетно-экспериментального исследования меха- \\ низма распространения трецины на начальном этапе вязкого разрушения корпусньх сталей \\ АЭС. Использован микромеханический подход к прогнозированио вязкого разруиения, \\ согласно которому объемное содержание пор деформируемого материала определяется \\ методом конечных элементов. На основании проведенньх испьтаний образиов СТ с тре- \\ циной и имеюиихся данных о параметрах разруиения гладких сферических образиов уста- \\ новлен ликромеханический критерий начала развития трецинь в условия вязкого разру- \\ шения материала.
}

Ключевые слова: комплексное микромеханическое моделирование, доля объемных пустот, метод конечных элементов, критерий развития трецины.

Introduction. Micromechanism of ductile fracture of most metals and alloys includes void nucleation, growth and coalescence. In steels, voids nucleate at non-metallic inclusions and second-phase particles. Micromechanical approach to fracture mechanics has been introduced in an effort to describe the process of fracture in a way that is as close to the actual phenomena in a material as possible. Such an approach is based on the models that account for and quantify the process of microscopic damages, in order to predict macroscopic failure.

Micromechanical approach to the analysis of ductile fracture requires combined experimental and numerical procedure. According to the uncoupled micromechanical damage models, the damage parameter is calculated in postprocessing phase of the finite element (FE) analysis. In the coupled micromechanical models, one or more damage parameters are calculated to 
predict ductile fracture initiation. Thus, the FE analysis must include procedure for calculation of these parameters and optionally, fracture initiation criterion. The most frequently used damage parameter is void volume fraction, $f$.

In present study, we apply micromechanical model based on a particular yield criterion of a porous solid, proposed by Gurson [1] and later modified by Tvergaard and Needleman [2,3] (the GTN model). This model was incorporated into the software program using FE method. The present research is a continuation of the Round Robin project [4], aimed at defining the criterion of the crack growth onset on CT specimens using values of micromechanical parameters determined on simple round specimens.

Micromechanical Model. Coupled approach to the material damage and ductile fracture initiation considers alloy as a porous medium where the influence of nucleated voids on the stress-strain state and plastic flow cannot be avoided. The GTN model is based on the hypothesis that void nucleation and growth in metal may be macroscopically described by extending the von Mises plasticity theory to cover the effects of porosity occurring in the material. Thus the void volume fraction $f$ as a variable is introduced into expression for plastic potential [1-3]:

$$
\phi=\frac{3 \sigma_{i j}^{\prime} \sigma_{i j}^{\prime}}{2 \sigma^{2}}+2 q_{1} f^{*} \cosh \left(\frac{3 \sigma_{m}}{2 \sigma}\right)-\left[1+\left(q_{1} f^{*}\right)^{2}\right]=0,
$$

where $\sigma$ denotes actual yield stress of the material matrix, $\sigma_{i j}^{\prime}$ is the stress deviator, while $q_{1}$ is the constitutive parameter introduced by Tvergaard [2] to improve the ductile fracture prediction of the Gurson model, and $f^{*}$ is a function of the void volume fraction [3]:

$$
f^{*}= \begin{cases}f & \text { for } f \leq f_{c} \\ f_{c}+K\left(f-f_{c}\right) & \text { for } f>f_{c}\end{cases}
$$

where $f_{c}$ is the critical value at which void coalescence occurs. Parameter $K$ defines slope of the sudden drop of the load on the load-diameter reduction diagram and is often referred to as "accelerating factor." For $f^{*}=0$, the plastic potential [Eq. (1)] is identical with that of von Mises.

Initial void volume fraction $f_{0}$ depends on the volume fraction of non-metallic inclusions in steel, $f_{V}$. Under plastic strain, voids in the material matrix first nucleate on these non-metallic inclusions. In the final stage of ductile fracture, the voids may intensively nucleate on the secondary-phase particles (the so-called secondary voids).

Tested Steel. The low-alloyed pressure-vessel steel of designation 22NiMoCr37 according to the German standard (DIN) has been tested. The experiments have been carried out on the specimens of steel in forged heat-treated condition. The steel was produced at Siemens and used in [5].

The chemical composition of steel is given in Table 1 .

Major mechanical properties of tested steel are: $R_{p 0.2}=476 \mathrm{MPa}, R_{m}=$ $=620 \mathrm{MPa}$, and $E=203,000 \mathrm{MPa}$. Optical microscopy of etched specimens has 
shown that tested steel consists of polygonal ferrite and beinite. Using planimetric method of measurement on the specimens in polished state according to ASTM E 1245-89, it has been established that the steel contains non-metallic inclusions of sulfide and oxide type and a number of complex oxide-sulfide inclusions. Determined mean value of non-metallic volume fraction is $f_{V}=0.00236$. Average value of mean free path between inclusions is $\lambda=243.1 \mu \mathrm{m}$.

$\mathrm{T}$ a b 1 e 1

Chemical Composition of Steel 22NiMoCr37 (in wt.\%)

\begin{tabular}{|c|c|c|c|c|c|c|c|c|c|}
\hline $\mathrm{C}$ & $\mathrm{Si}$ & $\mathrm{Mn}$ & $\mathrm{P}$ & $\mathrm{S}$ & $\mathrm{Cr}$ & $\mathrm{Mo}$ & $\mathrm{Ni}$ & $\mathrm{Cu}$ & $\mathrm{Al}$ \\
\hline 0.22 & 0.21 & 0.86 & 0.018 & 0.011 & 0.42 & 0.83 & 0.92 & 0.05 & 0.015 \\
\hline
\end{tabular}

Results and Discussion. The critical value of void volume fraction $f_{c}=0.00611$ has been determined by experimental and numerical procedures of testing of smooth round specimens. At this value of $f_{c}$ in the center of a smooth specimen final loss of the material loading capacity occurs, followed by fracture. Optical and scanning electron microscopy and FE elastic-plastic calculations have shown that the influence of the secondary-phase particles on the final phase of ductile fracture of tested steel is low $[6,7]$. Therefore it is here assumed that the initial void volume fraction corresponds to the volume fraction of non-metallic inclusions, $f_{0}=f_{V}$, while the influence of the secondary-voids nucleation is neglected.

For determination of the onset of stable crack growth at the beginning of ductile fracture, the CT25 specimens $(B=25 \mathrm{~mm}, W=50 \mathrm{~mm})$ with $a_{0} / W \approx 0.55$ were used. Using the "single specimen method," force-crack mouth opening displacement diagram $(F-C M O D)$ and the resistance curve to the crack growth, $J-\Delta a$ (Fig. 1) have been determined.

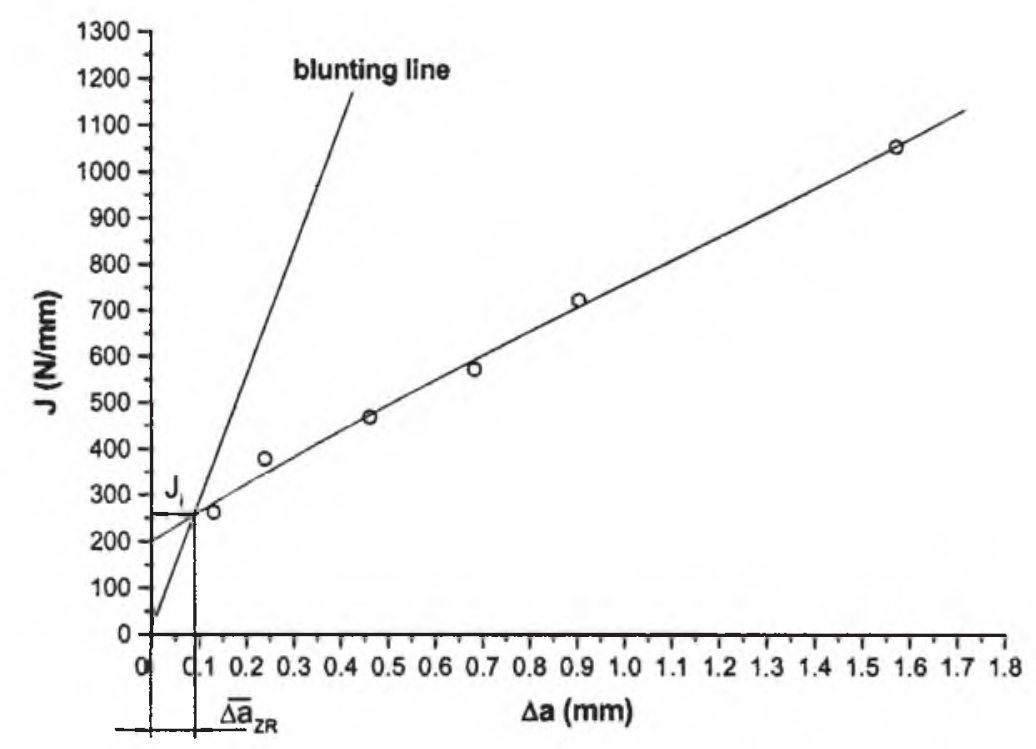

Fig. 1. $J-\Delta a$ curve and blunting line. 
According to the ESIS procedure [8], through the experimental points a polynomial of third order has been drawn in Fig. 1 that in proper way represents the curve of resistance. The blunting line has been located according to the mean value of final stretch zone width $\Delta \bar{a}_{Z R}=91.15 \mu \mathrm{m}$ determined by measurement on three broken CT specimens according to [9]. Bisection of the blunting and polynomial has given the value of $J$-integral corresponding to the onset of crack growth: $J_{i}=259 \mathrm{~N} / \mathrm{mm}$, according to [8]. The value obtained for $J_{i}$ is rather high, which indicates a very good resistance to the mechanism of the onset of ductile fracture for the tested pressure-vessel steel.

One half of the specimen has been numerically modeled using a mesh of finite elements (FE) in a plane. Eight-node isoparametric FE under conditions of plane strain is used (Fig. 2). The material non-linearity is modeled by a curve true stress vs true (logarithmic) strain. Loading is modeled by a large number of prescribed displacements of a node on the left edge of the mesh (Fig. 2a).

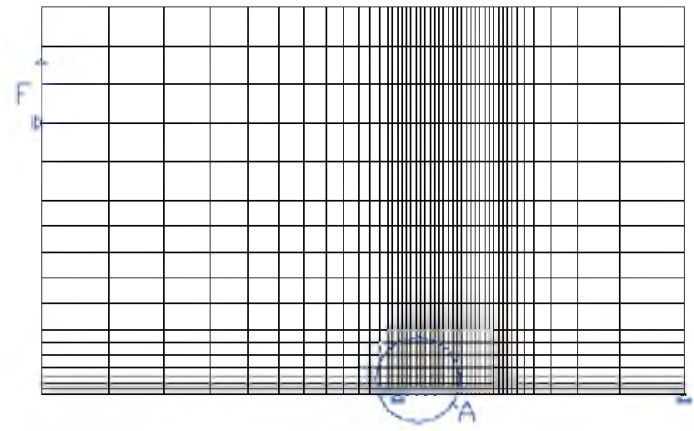

$a$

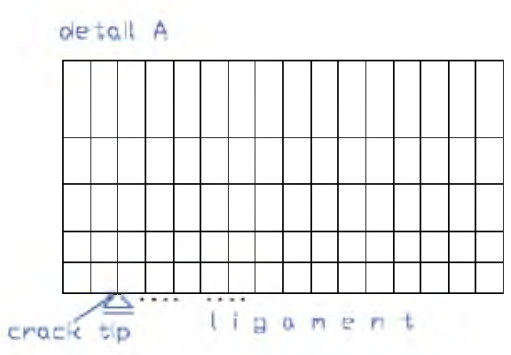

$b$

Fig. 2. Finite element mesh for CT25 specimen (a) and crack tip detail (b).

Crack tip is modeled solely by a FE-mesh refinement in the crack zone (Fig. 2b). It has turned out [10] that the FE-size in front of a crack tip significantly affects the accuracy of modeling of crack growth initiation. The question is how to define the FE size at a crack tip and get an actual result at the beginning of a crack growth for the parameters of fracture mechanics that quantify the onset of a crack growth: $J$-integral $\left(J_{i}\right)$ or crack tip opening displacement, CTOD $\left(\delta_{5 i}\right)$.

It has been shown elsewhere [10] that, in case of application of the reduced Gauss integration, the FE size in front of the crack tip approximates to an average value of the mean path $\lambda$. This result is in accordance with previous research [11, 12]. Therefore the FE size of $0.25 \times 0.25 \mathrm{~mm}$ in ligament is adopted. The quadratic FE is used, since no significant influence of test direction on the mean free path $\lambda$ has been observed [10].

Figure 3 shows diagram $F-C M O D$ up to the moment of the onset of the crack growth. A very good agreement of experimental and numerically calculated curves is obtained. 


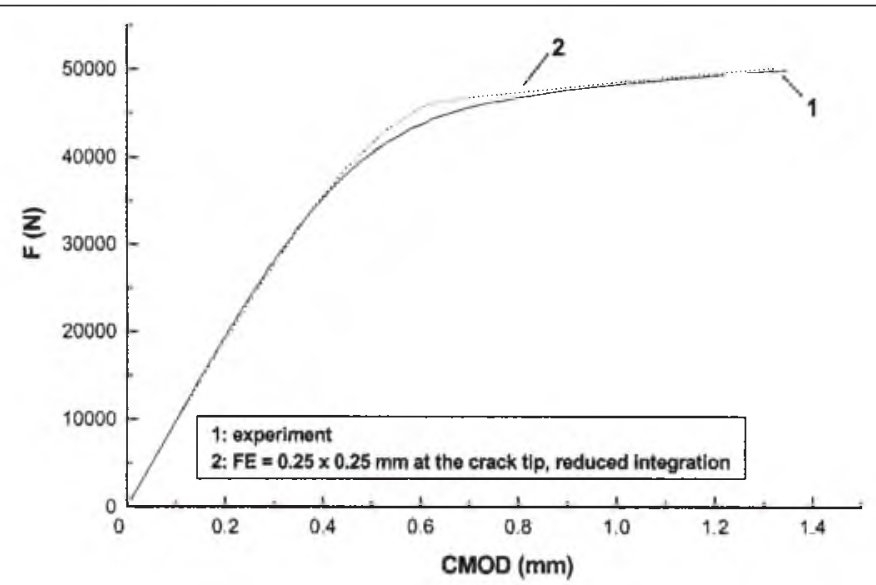

$a$

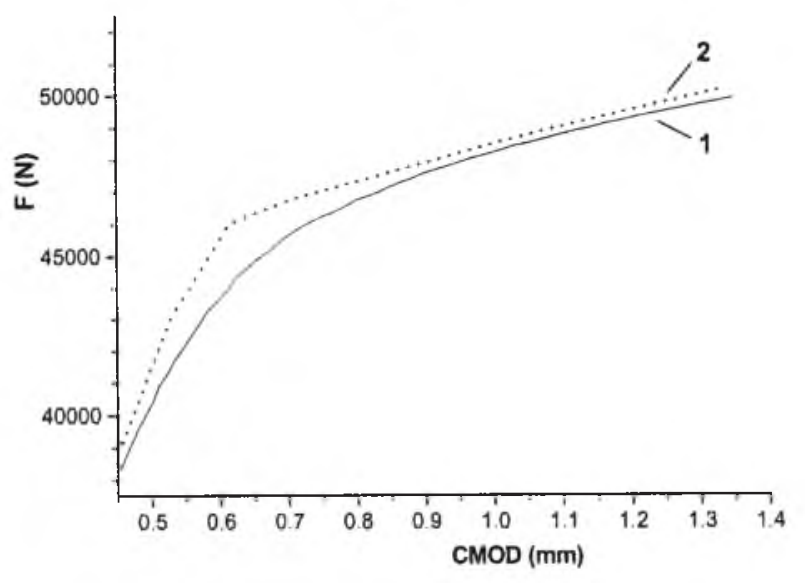

$b$

Fig. 3. Diagram $F-C M O D(a)$ and magnification at crack growth initiation point (b).

$J$-integral corresponding to the onset of the crack growth has been calculated based on the work of an external force, below the numerically obtained curve, according to [8]. Failure criterion has been defined by

$$
f \geq f_{C},
$$

where $f$ is a void volume fraction determined by elastic-plastic FE calculations, and $f_{c}=0.00611$ is critical void volume fraction. The crack begins to grow when the criterion given by [3] is satisfied in any of the Gauss points in a FE nearest to the crack tip. In this way $J_{i}=270.4 \mathrm{~N} / \mathrm{mm}$ has been calculated, which is in a very good agreement with the experimental value.

Conclusions. In this research, using coupled micromechanical analysis, the onset of the crack growth in CT specimens has been successfully foreseen, based on the critical void volume fraction $f_{c}$ (determined on smooth round specimens) and mean free path $\lambda$. Further research envisages modeling of a stable crack growth. 


\section{Рез нме}

Представлено результати комплексного розрахунково-експериментального дослідження механізму розповсюдження тріщини на початковому етапі в'язкого руйнування корпусних сталей АЕС. Використовується мікромеханічний підхід до прогнозування в'язкого руйнування, згідно з яким об'ємний вміст пор деформівного матеріалу визначається методом скінченних елементів. На основі проведених випробувань зразків СТ із тріщиною та відомих даних про параметри руйнування гладких сферичних зразків установлено мікромеханічний критерій початку розвитку тріщини в умовах в'язкого руйнування.

1. A. L. Gurson, "Continuum theory of ductile rupture by void nucleation and growth: Part I. Yield criteria and flow rules for porous ductile media," $J$. Eng. Mater. Techn. 99, 2-15 (1977).

2. V. Tvergaard, "Influence of voids on shear band instabilities under plane strain conditions," Int. J. Fract., 17, 389-407 (1981).

3. V. Tvergaard and A. Needleman, "Analysis of cupe-cone fracture in a round tensile bar," Acta Met., 32, 157-169 (1984).

4. G. Bernauer and W. Brocks, Numerical Round Robin on Micromechanical Models - Results, ESIS TC8, Institute for Materials Research, GKSS Research Center, Geesthacht (2000).

5. J. Heerens and D. Hellmann, Fracture Toughness of Steel in the Ductile to Brittle Transition Regime, Final Report of the EU-Project MAT1-CT-940080, GKSS Research Center, Geesthacht, (1999).

6. M. Rakin, Z. Cvijovic, A. Sedmak, and S. Sedmak, "Analysis of the transferability of micromechanical parameters of damage of steel under conditions of ductile-fracture initiation," Mater. Sci., 38, 104-113 (2002).

7. M. Rakin, Z. Cvijovic, and A. Sedmak, "Study of physical significance of some micromechanical parameters in ductile fracture analysis," in: Book of Abstr. of ESIS TC1 and TC8 Spring Meeting, (Paris, France, 2002), ESISCEA, Paris (2002), p. 13.

8. ESIS Procedure for Determining the Fracture Behavior of Materials, European Structural Integrity Society, ESIS P2-92 (1992).

9. Ermittlung von Rissinitierungswerten und Risswiderstands-Kurven bei Anwendung des J-Integrals, DVM 002, Deutscher Verband for Materialprüfung (1987).

10. M. Rakin, Z. Crijovic, V. Grabulov, S. Putic and A. Sedmak, "Prediction of ductile fracture initiation using micromechanical analysis," Eng. Fract. Mech. (in print).

11. D-Z. Sun, R. Kienzler, B. Voss, and W. Schmitt, in: Fracture Mechanics (Twenty-Second Symp.), Atluri S. N., Newman J. C., Raju Jr. I., and Epstein J. S. (Eds.), ASTM STP 1131, Vol. II, Philadelphia (1992), pp. 368-378.

12. C. Poussard and C. Sainte Catherine, "CEA Contribution to the ESIS TC8 Round Robin on numerical methods," Phase II, Task A, ESIS TC8 Meeting, Swansea (1999). 